\title{
Forest growth trends in Canada
}

\author{
by Craig Loehle1,"* and Kevin A. Solarik²
}

\section{ABSTRACT}

Reports have identified changes in abiotic factors that potentially affect forest growth. A synthesis of studies of these changes in Canada over the past century was undertaken to evaluate how these factors may be influencing forest growth. Reviewed papers used multiple sources of data including long-term inventory plots, tree-ring reconstructions, historical geographic data, and forest growth models. The synthesis showed that several positive growth trends were found in British Columbia and eastern Canada, while results from the western interior of Canada were mixed. Trembling aspen (Populus tremuloides Michx.) dieback has been noted due to severe and prolonged drought events, with growth reductions and mortality also documented for conifers in the western interior. Studies have also found slow forest expansion in many areas and at the northern tree-line. Overall, authors attributed positive forest growth trends to rising $\mathrm{CO}_{2}$ concentrations, $\mathrm{N}$ deposition, increased precipitation, and increased temperature. Growth declines were generally attributed to a combination of increased temperatures and reduced precipitation. Studies also differed due to time periods considered and how age effects were corrected. Methodological issues were identified that led to contradictory results between some studies. These issues need further study.

Keywords: Canada; climate change; environmental factors; forest growth and yield; forest growth trends; inventory data; remote sensing; precipitation; temperature; nitrogen; carbon

\section{RÉSUMÉ}

Des études ont identifié des modifications dans les facteurs abiotiques susceptibles d'affecter la croissance de la forêt. Une synthèse des études sur les changements survenus au Canada au cours du siècle dernier a été entreprise pour évaluer dans quelle mesure ces facteurs abiotiques peuvent influer sur la croissance de la forêt. Notre synthèse a mis en évidence plusieurs tendances positives de croissance en Colombie-Britannique et dans l'est du Canada, et des résultats mitigés pour l'ouest de l'intérieur du Canada. Un dépérissement du peuplier faux-tremble (Populus tremuloides) ainsi qu'une réduction de la croissance et une augmentation de la mortalité pour les conifères de l'intérieur de l'Ouest ont été observées après des épisodes de sécheresses graves et prolongées. Certaines études ont également révélé une lente expansion de la forêt dans de nombreuses zones et à la limite des arbres au nord. Dans l'ensemble, les auteurs ont attribué les tendances positives de la croissance des forêts à l'augmentation des concentrations de $\mathrm{CO}_{2}$, à la déposition d'azote, à l'augmentation des précipitations et à l'élévation de la température. Au contraire, les baisses de croissance ont généralement été attribuées à une combinaison de températures plus élevées et de précipitations réduites. Les études examinées ont utilisé plusieurs sources de données, notamment des placettes d'inventaire à long terme, des données sur les anneaux de croissance des arbres, des données géographiques historiques et des modèles de croissance de la forêt. Les études différaient également selon les périodes considérées et la manière de corriger les effets sur l'âge avaient été corrigés. Des problèmes méthodologiques ont également été identifiés et ont conduit à des résultats contradictoires entre certaines études, nécessitant des études supplémentaires.

Mots clés: Canada; changement climatique; facteurs environnementaux; croissance et rendement des forêts; les tendances de croissance de la forêt; données d'inventaire; télédétection; précipitation; température; azote; carbone

\footnotetext{
${ }^{1}$ National Council for Air and Stream Improvement, Inc., 1258 Windemere Avenue, Naperville IL 60564 USA; * Corresponding author email: cloehle@ncasi.org

${ }^{2}$ National Council for Air and Stream Improvement, Inc., 2000 McGill Avenue, $6^{\text {th }}$ Floor, Montreal QC H3A 3H3 Canada
} 


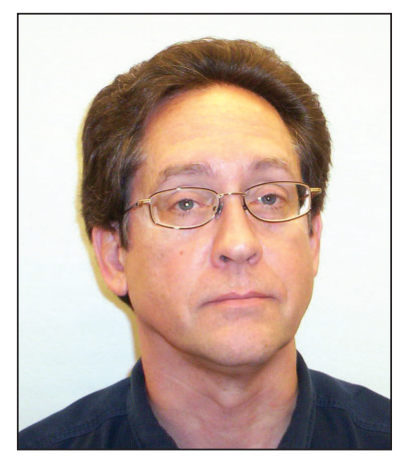

Craig Loehle

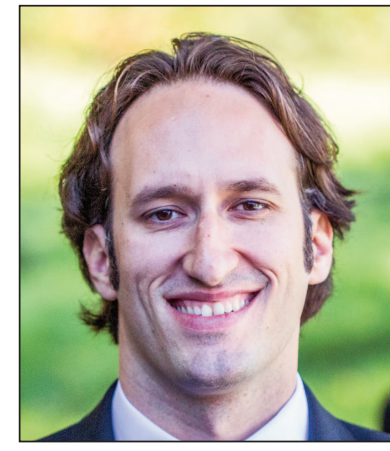

Kevin A. Solarik

\section{Introduction}

Canadian forests represent a major carbon store (Pregitzer and Euskirchen 2004; Ter-Mikaelian et al. 2015). Changing conditions (e.g., fire, warming) could lead to either a large source or sink for forest carbon in coming decades. This is especially so if climate change disproportionately leads to greater warming at high latitudes (see Serreze et al. 2000). In addition, the health of Canada's forests is of critical interest to society, public and private forest landowners, and the forest products industry, both in terms of commercial value and for providing ecosystem services. Many studies have reported changes over the past century in climate-related and other environmental factors that may influence forest health and growth such as fire frequency, ozone levels, nitrogen deposition, atmospheric $\mathrm{CO}_{2}$ concentrations, temperature, and precipitation (e.g., Serreze et al. 2000). Precipitation trends can influence forest area and density and are highly variable in time and space (Pederson et al. 2015). Rising $\mathrm{CO}_{2}$, by increasing growth rates (Higginbotham et al. 1985) and water use efficiency (Loehle et al. 2016), may mimic effects of rising precipitation and favors broadleaf species more than conifers. Rising temperature can lead to drought stress but has additive effects when combined with rising precipitation that would favor tree growth (Loehle et al. 2016). At higher elevations, rising temperature could cause tree-lines to expand upslope. In the far north, it could allow the boreal forest ecotone to expand into what is now tundra.

Environmental changes may adversely affect tree growth. Various authors (Allen et al. 2010, 2015; Anderegg et al. 2015; McDowell and Allen 2015; McDowell et al. 2016) have highlighted numerous large-scale forest mortality events globally and predicted that changing conditions will likely lead to further widespread forest mortality and/or dieback in the future. However, there is some evidence that forest growth may have increased over the past century. Recent forest growth surveys synthesizing various data sources have suggested that, on average, global forest growth is increasing (e.g., Boisvenue and Running 2006; Wang et al. 2017; Schulte-Uebbing and de Vries 2018). Such studies, however, may be confounded by forest regrowth following land abandonment, by successional stage changes in productivity, and by disturbance.

The contradiction between predictions that changing conditions should be having adverse effects on forests and evidence to the contrary needs resolution. It clearly affects determination of aspects of forest resource and ecosystem health. This report sets out to synthesize information on historical trends in forest growth in Canada to help resolve this uncertainty. We consider not strictly the boreal forest but all forest types in Canada.

In this synthesis, we are interested in the growth rate of existing stands in terms of site productivity rather than landscape-scale productivity, which can vary based on disturbance or successional stage. Considerable variability can also arise in how productivity is measured, which makes synthesizing results on the topic difficult. Ideally, productivity can be captured as area-based net primary productivity (NPP), but available data may be in terms of aboveground wood or tree increment. A standard metric for site quality in forestry is site index, which is average stand height of dominant trees (or similar metric) at a given age for even-aged stands. Trees generally have faster height growth under better growing conditions. Stand basal area, when combined with height, is a good predictor of total stand biomass because individual tree biomass can be predicted from allometric equations. Growth models can likewise be used to predict stand biomass and NPP. We expect that if precipitation increases, trees may expand into grassland at dry margins and, if the climate warms, forest may expand at cold margins. Finally, forest dieback and/or ecotone retreat is a negative indicator. All these metrics are roughly correlated indicators of growing conditions.

A frequently used metric for tree growth is detrended ring width. Detrending accounts for the normal decrease in ring width due to stem geometry and tree age. A problem with detrending arises if a gradual change occurs over time due, for example, to slowly rising carbon dioxide, the effect of which will be correlated with tree age. The age detrending methods, of which there are many, used to adjust growth histories to account for tree aging and stem geometry can, in many cases, dampen a long-term growth signal (i.e., any historical trend) by confounding it with tree age (Esper et al. 2004, 2005a, 2005b, 2007; von Storch et al. 2004), though Franke et al. (2013) argued that such detrended series exaggerate low-frequency signals. When stand density can change over time (due to ingrowth or mortality), standardization is further compromised (Cherubini et al. 1998; Carrer 2011; Nehrbass-Ahles et al. 2014). Given this controversy and the complex interactions between stand structure, individual tree growth, and total productivity (Forrester 2019), we felt it was prudent to avoid studies that used detrended ring data. An approach that overcomes these issues is to use age-matching to compare trees at the same age but different establishment dates. If old trees are available, an age-ring width model can be developed. For example, for trees established prior to 1900, a 100-year-long (or more) empirical relationship can be established without using any rings laid down after 1900 (the start of the period of interest). Then, deviations in growth from this model can be examined over the period of interest for younger trees. This method removes concerns about standardization (i.e., no detrending is done) and allows one to evaluate trees in stands (not open-grown). One caution is that there may exist growth rate trade-offs with mortality, such that very old trees may be slower growing (Loehle 1988, 1996), creating a bias toward detecting recent increased growth with age-matching.

Inventory plots can be used to estimate growth of either wood volume or NPP (aboveground or total) using various 
methods (Talbot et al. 2014; Searle and Chen 2017b; Kohyama et al. 2019). To estimate growth rate changes, at least three inventory-based estimates are needed (e.g., 1995, 2000, 2005), where each pair (e.g., 1995-2000) gives an estimate of growth rate to compute a change of rate. Ideally, two pairs of years (e.g., 1980-1985 vs. 2000-2005) would provide two estimates of growth rate. Various complications exist, but most are not critical in Canadian forests. High turnover during long sample intervals, for example, is a larger problem in tropical forests where trees can grow into a plot, die, and decay before being sampled. Slow growth and decay rule out this problem in Canada. Size thresholds (e.g., $5 \mathrm{~cm} \mathrm{dbh)} \mathrm{for}$ sample inclusion may bias NPP down slightly, but the low rates of ingrowth in Canadian stands compared to tropical forest (Johnstone and Chapin 2003) make this a minor issue. Other inaccuracies in estimating growth, per above, are minor or are minimized if the same methods are used over time as we are interested in growth rate changes rather than absolute rates.

Comparison of stand growth rates over time must consider stand age. The net effect of stand dynamics for evenaged stands is an area-based pattern of accelerating growth, a peak shortly after crown closure, and a long decline period (Girardin et al. 2011a; Kashian et al. 2013; Boisvenue et al. 2016; Hogg et al. 2017). This dynamic can be captured using Hoerl's function (Eq. 1).

\section{(1) $\triangle A G B=\beta_{0}\left(\right.$ age ${ }^{\beta}{ }_{1} e_{2}{ }_{2}($ age $)$}

where $\beta_{0}, \beta_{1}, \beta_{2}$ are fitted parameters and $\triangle A G B$ is above ground biomass increment per year per ha. In Fig. 1, a typical curve for Canadian species as estimated (their Fig. 6) by Boisvenue et al. (2016) is shown. The decline phase is par- tially due to increased mortality resulting from crowding and tree aging (Hogg et al. 2017) and reduced hydraulic efficiency with age (Baret et al. 2018). Growth response of older stands could thus be misleading if a reduction in growth results from maturation rather than changes in environmental conditions. For example, Goulden et al. (2011) showed that the largest stand-level mass gain in black spruce (Picea mariana (Mill.) BSP) in central Manitoba occurred between ages 40 and 74 , with much less by age 154 , at which point ( $>154 \mathrm{yr}$ ) minimal gain was evident. Likewise, Dunn et al. (2007) found a net above-ground tree carbon balance of near zero over 1994-2004 for a 160-year-old bog black spruce forest. In northern Minnesota, growth variations due to climate were 92-95\% smaller than those due to tree size and age (Foster et al. 2016). Likewise, Chen et al. (2016) documented young stands to have the greatest growth increase over 1958-2011 in interior western Canada. According to Zhang et al. (2015), competition was a major factor in reducing growth and increasing mortality in interior western Canada. Considerable variation in stand aging across Canada due to different degrees of disturbance (which creates younger stands) was shown by Kurz and Apps (1999) over the 1920-1979 period.

A strong positive correlation between NPP and tree mortality (Stephenson et al. 2011) has been widely observed. One reason for this is that competition for light is spatially constrained. To grow larger, a tree must expand its crown, but this is necessarily at the expense of neighboring trees. Those individuals that are overtopped will show decreased growth and may eventually die (Stephenson et al. 2011). Fertilization can speed up the self-thinning process (e.g., Yang 2006) by amplifying initial height growth differences. To the extent that nitrogen fertilization, rising $\mathrm{CO}_{2}$, and other climate factors increase growth rates, they could also lead to more rapid

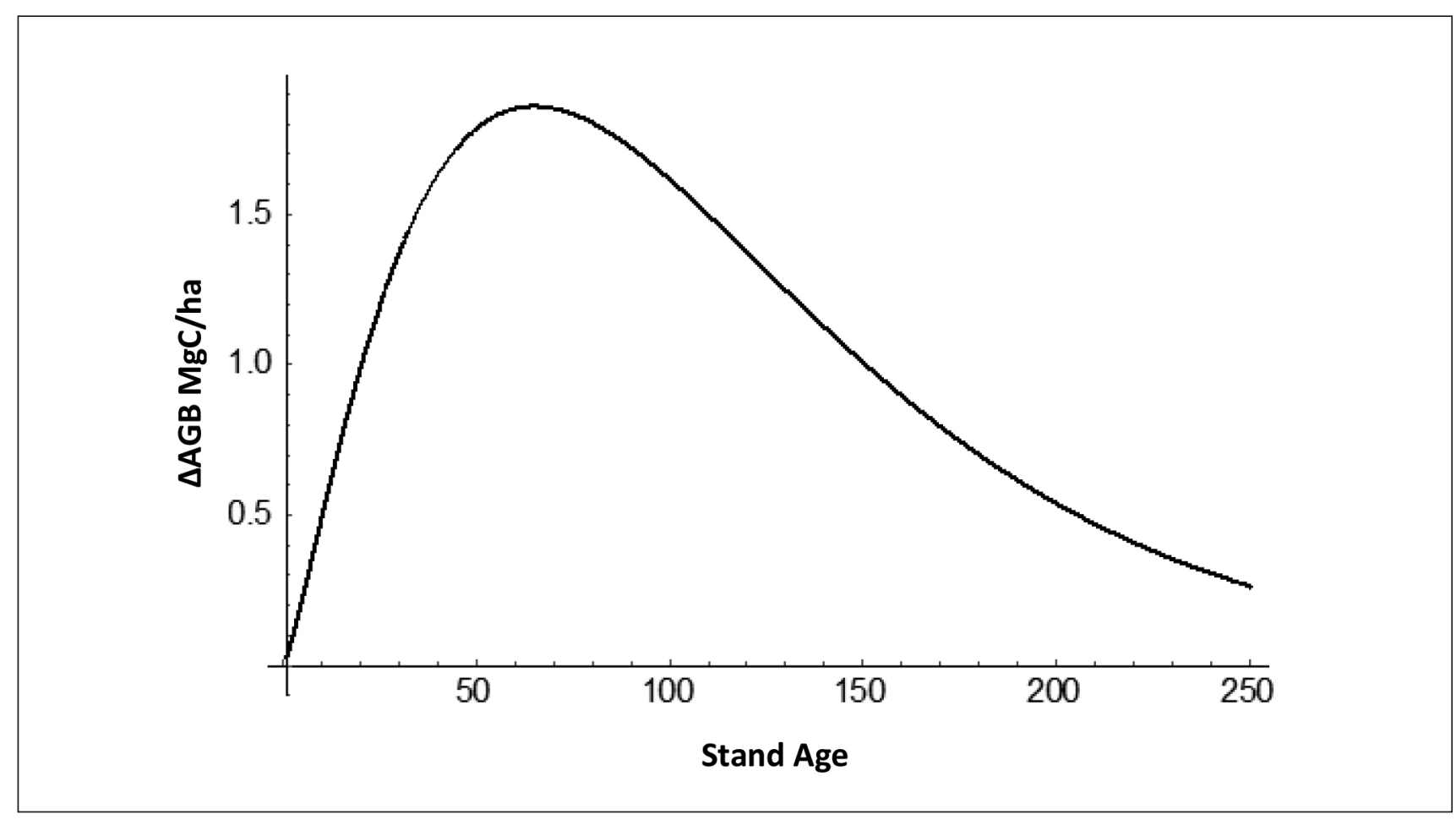

Fig. 1 Typical growth curve (Hoerl's function) for Canadian trees in even-aged stands on a unit area basis (based on Boisvenue et al. 2016) 
self-thinning and thus increased mortality, primarily in subordinate trees. For short-lived trees, a stand that is overmature will exhibit a rise in mortality, even of dominant individuals, especially with the imposition of stress (e.g., Worrall et al. 2013). Thus, any study that quantifies mortality alone, for example from forest inventory data, may come to the opposite conclusion in terms of effects and trends compared with data on NPP, height growth, stand basal area, or other more appropriate measures of stand growth.

Height growth of dominant trees, commonly used to construct site index metrics, is less affected by competition (Bontemps et al. 2011) and could provide a useful approach for estimating growth trends. In plantations, where spacing and age are uniform, height at a given age for older and younger stands could be compared either from inventory data or from tree dissections, although similar sites should be compared (Lieffers et al. 2018). For plantations on similar sites, yield tables from past harvests or tree sizes (height or biomass) at given ages can be validly compared. Planting density must be the same, as should treatments (e.g., thinning, fertilization), for such comparisons to be valid. Genetic improvement of planting stock over time could also confound results.

Finally, short- versus long-term data may show different trends. A region that is experiencing increased growth over the past 100 years due to changing climate factors (e.g., precipitation, temperature) and/or rising $\mathrm{CO}_{2}$ might nevertheless show a recent short-term decline in growth due to drought, pests, or stand aging, and conversely. It is therefore important to consider multiple sites and the longest time periods possible.

An additional indicator of forest response is a change in forest area or density. A complicating factor in understanding forest area change is that multiple processes can produce observed changes, and these processes do not change uniformly in space. Fire has historically been an important force determining forest/shrub or forest/grassland ecotone boundaries. Decreased fire frequency and/or intensity can allow a forest to expand at the dry range limit and become denser. Fires in North America were more common 100 to 150 years ago due to intentional human ignitions in the past and more recent fire suppression efforts (Taylor et al. 2016; Addington et al. 2018). In Canada, there has been a strong increase in area burned since the 1970s that has been attributed to climate warming (Gillett et al. 2004). Despite this uptick, a reconstruction of Canadian fire histories from the mid-1700s (Bergeron et al. 2004) indicates that historical fires were more common across Canada than in recent decades. Initially, areas recently burned with high-intensity fire may be difficult to distinguish from forest loss, particularly with satellite imagery, even though forest regeneration may be ongoing (Martinez-Vilalta and Loret 2016). In this review, our concern is with tree growth rates per se rather than carbon sources or sinks that might be impacted by fire. Because we view ecotone shifts as indicators of growing conditions, we took care to consider only ecotone shifts resulting from nonfire processes.

Remote sensing can capture large-extent changes in forest growth. However, if large areas are denuded by fire or insect outbreaks, corresponding reductions in leaf area will result in estimates of a large NPP drop. While this is technically correct and does provide data on forest-wide carbon sequestra- tion, it does not elucidate growth trends in remaining forest areas unless careful areal masking of denuded areas is undertaken. In addition, some serious inconsistencies have been found among and within (over time) remote sensing products (e.g., Guay et al. 2014; De Kauwe et al. 2016; Jiang et al. 2016) and between remote sensing results and Earth system model calculations (Smith et al. 2016) or field-based methods (e.g., Marchand et al. 2018). For example, Buermann et al. (2013) showed that a trend toward earlier springs in Canada since 1982 has led to a change in the seasonal profile of NPP such that the peak month NPP value has decreased while the entire growing season NPP value has increased. Remote sensing products based on any particular month (instead of the entire growing season) could, therefore, give misleading trend estimates and conclusions. For these reasons, remote sensing studies are not included in this review. For a summary of recent remote sensing studies in Canada, see Marchand et al. (2018).

From the above, it is clear that there are pitfalls in all available methods for determining growth trends. Old stands will show declining growth over time unrelated to climate or other growing conditions. Some species and age classes are more responsive to $\mathrm{CO}_{2}$ fertilization than others, and tree ring studies and mortality data can be confounded due to competition and stand dynamics. In this review, available studies are evaluated in this comprehensive context.

\section{Methods}

The scientific literature was searched for references to longterm growth trends of forests in Canada. As an initial entry to the literature, the contents of Forest Ecology and Management (2012-2018), Forest Science (2014-2018), Canadian Journal of Forest Research (2014-2018), Global and Planetary Change (2014-2017), and Global Change Biology (2012-2018) were accessed and every title (+6000 articles) was read and assessed. Then the literature was searched with Google Scholar using the following key-words: "forest history", "forest decline", "forest and climate", "NPP", "forest productivity", and "forest growth trends". These searches turned up several thousand articles. The cited literature in each relevant publication identified through the journal and online searches was then evaluated. Literature cited by Marchand et al. (2018) was also re-evaluated in the context of the cautions we have noted. Because of complications caused by tree ring standardization in closed stands, effects of stand age, and other methodological issues, results of reviewed studies had to be parsed carefully rather than taken at face value. Some studies were not used because text and graphical results could not be reconciled or the methods for data treatment were possibly confounded. The growth metrics used in reviewed studies were often based on forest inventory data and were thus measures of above ground tree biomass. Some models reported NPP.

\section{Results}

Forty-eight publications that quantified forest growth trends over time were found, plus numerous supporting references. Reviewed studies estimated forest growth rates or responses over periods ranging up to $300+$ years. Studies used a variety of approaches including plot-based reconstructions (8), model-based reconstructions (8), long-term photographic or 
map-based evidence of areal extent changes (14), height growth rate changes (3), and inventory-based studies of mortality (15). As noted in the introduction, methods developed for tree ring standardization of open-grown trees have not been shown to work (and we believe they are not valid) in closed stands due to effects of stand dynamics and competition. Nine otherwise relevant studies that used detrended ring width series that either focused on climate signals or that did not use all trees on a plot thus could not be used (Brooks et al. 1998; Watson and Luckman 2002; Berner et al. 2011; Bond-Lamberty et al. 2014; Girardin et al. 2014, 2016a, 2016b; Chen et al. 2017, 2018). Ma et al. (2012) conducted an analysis of plot-based biomass change from western Alberta across to eastern Québec. While they attempted to age-correct stand growth, most stands were over 100 years old, and thus not in their rapid growth phase. Because it is not clear how age correction was completed and considering the stand ages, this study could not be used. Several potentially useful studies which followed stands over time and estimated growth curves approximating Fig. 1 could not be used here (e.g., Dietrich et al. 2016; Metsaranta et al. 2018) due to age/time confounding (i.e., age correction was not done).

In the following sections, results are presented and organized by study type. This was done because study type influences the nature of data, possible confounding, and how data can be interpreted. For example, modeling studies share certain limitations and assumptions.

\section{Changes in forest ecotones, area, and density}

The most common forest response worldwide over the past $100+$ years has been expansion and/or densification (Nelson and Reams 2017; Stevens et al. 2017). A general upward elevational shift has been found for Europe (Lenoir et al. 2008) and globally (Harsch et al. 2009), though not at every location. Forest expansion into grassland/shrubland types or tundra/alpine areas, and increased tree density, indicates either that conditions for tree growth are improving or that there is recovery after fire or other disturbance. Shifts in overall geographic ranges are not evaluated here.

Jackson et al. (2016) used historical aerial photography from 1962 and 2005 (43 years) on Mount Albert Edward in British Columbia, Canada to evaluate ecotone shifts. They found that woody cover increased from $75 \%$ to $81 \%$ of the area, largely by infilling of gaps. Change in tree abundance was difficult to separate from woody cover per se. Conway and Danby (2014) measured tree size and age on forest ecotone transects in southwestern Yukon, Canada across 28 sites in two regions. They found that trembling aspen (Populus tremuloides) and some white spruce (Picea glauca (Moench) Voss) were encroaching into grassland at nearly every location on flat terrain and south-facing slopes. Trembling aspen spread was positively associated with rising spring temperatures and precipitation. There was no spread of trembling aspen on white spruce-dominated north-facing slopes. On slopes, this expansion was downhill rather than uphill, which was the opposite of expected patterns (uphill) from warming.

Other studies of elevational tree-lines in Canada have generally found some upward spread. Payette (2007) found a tree-line expansion of several tens of metres over the most recent 50 years in coastal northern Labrador. Brink (1959) showed some expansion of tree seedlings into heath in British
Columbia (about $100 \mathrm{~m}$ based on photographs) over an unspecified time period, but not more than 100 years based on apparent tree ages. This older study reinforces the notion that measurable tree migration rates require long time frames. Danby and Hik (2007) found an elevational shift of tree-line of 65-85 m over about 100 years on south slopes, but no change on north slopes at sites in southwest Yukon. Laroque et al. (2000) found episodic tree recruitment above the existing forest on southern Vancouver Island, but did not document expansion rates. Kearney (1982) attributed tree recruitment above timberline in the Alberta Rockies to episodes of elevated minimum temperatures.

Responses at the northern latitudinal tree-line in Canada have so far been muted. While recent trends are for increased tree growth and seedling establishment in response to warming, this has been largely within the existing forest margin zone, which was mostly established as early as 1800 (Szeicz and MacDonald 1995; MacDonald et al. 1998). Payette (2007) reported a static tree-line on the northern Labrador plateau (away from the coast). This slow response is what would be expected for the very cold growing conditions (Brown and Vellend 2014; Rundel et al. 2014; Loehle 2018) and a lack of developed or suitable soil substrates (Solarik et al. 2018). At a site in northern Quebec, Payette et al. (1989) found that treeline growth had failed to recover from declines during the Little Ice Age. At the forest-tundra ecotone on the eastern shore of Hudson Bay, Caccianiga and Payette (2006) showed that white spruce has been gradually spreading north since the 1600 s, with very slow progression. The only documented cases of rapid shifts in tree-line are Lavoie and Payette (1994) of a 4-km expansion since the late 1800s in subarctic Québec and Lescop-Sinclair and Payette (1995) of a 12-km shift west along the eastern shore of Hudson Bay but, in both cases, expansion seems to have been entirely due to Krummholz (recumbent shrub form) conversion to upright growth forms rather than seedling spread. Johnstone and Chapin (2003) found that lodgepole pine (Pinus contorta Dougl.) appears to be still expanding northward in the Yukon Territory, though within already-forested areas.

The net effect of warming on tree-lines appears to be tens to hundreds of metres spread over 100 years or stable ecotones with some densification. Rapid spread seems confined to Krummholz recovery to tree status. Alpine and arctic treelines remain cold where seedling establishment is difficult, and growth is slow, as the above authors noted.

\section{Tree height growth rate studies}

Gamache and Payette (2004) studied a 300-km latitudinal transect in Québec from the southern forest-tundra to the shrub-tundra. Sampled in 1999, stem dissections allowed height (and thus height growth) to be determined back over 200 years for the oldest trees. It was found that the rate of height growth of black spruce since the 1970s progressively increased over the study period (1970s-1999) and was most pronounced in the 1990s. Trees at the range margins had experienced the largest growth increase, becoming comparable to more southerly trees. Topography played a complex role. Growth changes could not be quantified from their analyses.

In a study in British Columbia, Nussbaum (1998) developed site index equations for old-growth vs. logged and 
regenerated (LAR) stands. He found that LAR stands had an average site index $7.7 \mathrm{~m}$ higher for Douglas-fir, $4.3 \mathrm{~m}$ for lodgepole pine, and $6.6 \mathrm{~m}$ for spruce. This result could have several explanations. The first is that young stands are growing substantially faster than previously due to environmental conditions. The second is that the cultural practices involved in silvicultural regeneration improved forest growth. Nussbaum (1998) attributed the difference to a bias in estimating site index for old stands. Available information does not allow us to distinguish these possibilities, and all three could be involved. Finally, Huang et al. (2004), in Alberta, found height growth of lodgepole pine following harvest and site scarification to be $27-35 \%$ higher than for mature fire-origin forest at similar ages. Part of this could have been due to true increased recent growth for young stands. More study of this issue seems warranted.

\section{Mortality events}

Changes in mortality rates could indicate altered growing conditions. Allen et al. $(2010,2015)$ documented instances of drought-caused mortality globally, with instances in Canada included here, except for their bark beetle (Dendroctonus monticolae Hopkins) case in British Columbia. Insect outbreaks are historically part of this ecosystem and while the British Columbia bark beetle outbreak could be related to changing conditions, it is difficult to resolve causation in this case. Alfaro et al. (2014), for example, documented that regional spruce budworm (Choristoneura occidentalis Walsingham) outbreaks in southern British Columbia were observed back to 1500 , with similar frequency in the 1800 s and 1900s. Because the focus here is on non-disturbance causes of growth and mortality change, changes in frequency of insect outbreaks are outside the study scope. There is evidence for a recent trend of somewhat increased droughtcaused mortality in interior western Canada (e.g., Peng et al. 2011; Walker et al. 2015; Hember et al. 2017a). However, modest to major increases in mortality can be due to selfthinning and succession as stands age, as found by Thorpe and Daniels (2012) in their study in Alberta and Zhang et al. (2015) in interior western Canada, which complicates interpretation. Zhang et al. (2015) especially note that Peng et al. (2011) did not include changes in competition in their analysis.

As a dominant canopy tree in most regions of western Canada, trembling aspen has exhibited extensive mortality in some locations (see citations below). A complicating factor, however, is that trembling aspen is a relatively short-lived, disturbance-dependent species and thus, older stands will be inherently prone to mortality events. Hogg et al. (2005) studied the stand dynamics of trembling aspen across 25 sites in interior western Canada between 1951 and 2000. They found stand-level basal area increment (BAI) to have generally increased over the period, but this did not account for trees that died before their sampling date, or age effects. Further, BAI was strongly affected by available moisture (i.e., precipitation) and episodic, widespread defoliation and other damage caused by insects, with growth varying up to $50 \%$ over several-year intervals. This high variability combined with stand aging complicates interpretation of dieback events. A severe drought, for example, in interior western Canada in 2000-2002 caused severe mortality, especially in the drier aspen parkland (Hogg et al. 2008; Michaelian et al. 2011). Worrall et al. (2013) concluded that across its range, trembling aspen dieback was typically preceded by drought, tended to occur on marginal (i.e., drier) sites, and was exacerbated by insects and pathogens. While trembling aspen appears to be sensitive to drought, there is also evidence that sucker regeneration is common in the understory of stands experiencing dieback (Frey et al. 2004). A key factor in trembling aspen decline may be the influence of ungulate browsing on regeneration. Beschta et al. (2016) found that historical data on exclosures in Yellowstone National Park, Wyoming and recent fluctuations in Rocky Mountain elk (Cervus elaphus L.) populations both pointed to herbivory as a limiting factor for trembling aspen sucker success. In the northern part of the park, where Rocky Mountain elk abundance had declined, trembling aspen stands were recovering. Painter et al. (2014) and Rooney (2001) came to this same conclusion. The following thus seems plausible: all trembling aspen, but particularly older stands or those on dry sites, are prone to dieback and, when there is excessive herbivory, are unable to recover.

Several local declines have been documented. Ouimet et al. (2013) concluded that white spruce decline in south-central Québec during 1997-2008 was due to potassium (K) deficiency on certain soils. They noted that insect attack, which preceded the decline, tended to cause $\mathrm{K}$ leakage on these sites. Excess $\mathrm{N}$ from atmospheric deposition causes a nutrient imbalance that aggravates $\mathrm{K}$ deficiency. They reported that normalized difference vegetation index (NDVI), an indicator of leaf area, rose sharply during 1982-1991, perhaps resulting in too much leaf area for the available K supply.

Buma et al. (2017) documented a long-term decline in yellow cedar (Callitropsis nootkatensis D. Don) along coastal British Columbia and Alaska. This decline appeared to result from a shift from winter snow to a rain regime, which may result in the loss of snow cover protection of root systems. Wong and Daniels (2017) evaluated whitebark pine (Pinus albicaulis Engelm.) decline in the southern Canadian Rockies. Decline began in the 1940s, with peak mortality in the 1970s. They attributed decline and mortality to drought during a cool phase of the Pacific Decadal Oscillation $(\approx 1947-$ 1976), followed by an attack by the non-native blister rust pathogen (Cronartium ribicola J. C. Fisch.) and/or mountain pine beetle (Dendroctonus ponderosae Hopkins). General conclusions cannot be drawn from this local, historical mortality event. These three examples of decline are either local or due to unusual causes and are not indicative of widespread conditions.

Deriving a coherent picture of mortality trends is difficult. Periodic mortality caused by pathogens and insects (e.g., Morin et al. 1993) or by drought is undoubtedly a natural process. Historical data needed to establish a framework for comparison are currently lacking for each of these natural mortality agents such as historic patterns of drought. That is, documentation of rates of natural mortality under static conditions is lacking except for the self-thinning literature, which tends to focus on young stands. Evidence from long-term plots appears to be open to some interpretation; when natural stand aging is considered, rising mortality becomes more challenging to document. Ultimately, much more work is needed on this topic. 


\section{Model-based reconstructions}

Hember et al. (2017b) modeled regional forest growth across Canada at the stand level using historical climate and disturbance regime reconstructions. This simulated the changing age structure of the forest over time rather than being agecorrected or a standard age. The modeled interior western regions showed declines in net ecosystem biomass production (NEBP) during 1951-2012 but increases during 19612012 due to climate fluctuations. All other regions showed positive trends. Simulated stand age had small mixed effects across the five regions. Despite growth declines in the two drier regions, the net linear growth rate change was $+1.5 \% / y r$ over all of Canada.

Two studies by Girardin et al. (2011b, 2012) used tree growth indices, which are detrended. We have reservations about this method and thus focus on their model results. Girardin et al. (2012) used jack pine (Pinus banksiana Lamb.) and black spruce cores from unmanaged forests older than age 70 in Québec. Using a model for NPP and stands of all ages for 1950-2005, they obtained a $+5.1 \%$ increase for jack pine $(0.093 \% / y r)$ and $+2.1 \%$ for black spruce $(0.038 \% / y r)$. Girardin et al. (2011b) studied jack pine in Manitoba. Their model, based on standard even-aged canopy leaf areas, was used to simulate NPP during 1912-2000. They found that growth increased $5.4 \%$ over the 88 years or a $0.061 \% / y r$ linear trend. They estimated the effect of doubled $\mathrm{CO}_{2}$ to be only $+14 \%$ compared to the theoretical $23 \%$ based on experimental work.

Tei et al. (2017) specifically noted that tree ring analysis and modeling resulted in contrary responses in their study area, as we have been suggesting. Their model results showed large positive growth trends over the period 1951-2005 in eastern, southwestern, and west-coastal Canada. The interior northwest was mixed. Numerical trends could not be extracted from their figures.

In a study in British Columbia, Wu et al. (2014) evaluated data from 3432 long-term plots from 1956-2001. They calibrated the InTEC growth model to NPP determined by flux tower data to remove stand age effects (decreasing NPP with age) and estimated effects of $\mathrm{CO}_{2}$ and $\mathrm{N}$ deposition. They found a roughly $24 \%$ increase in NPP for maritime areas and $36 \%$ increase for inland (higher, cooler) areas. After correcting for forest age effects, the relative ranking (maritime vs. inland) flipped, and growth enhancements increased, but percent increases could not be determined from their agecorrected plots, which were on an anomaly basis. The authors found that $\approx 70 \%$ of the NPP increase was due to warming and most of the remaining increase was due to rising $\mathrm{CO}_{2}$ and $\mathrm{N}$ deposition.

Global NPP trends over 1901-2000 were simulated by Del Grosso et al. (2008), with fixed $\mathrm{CO}_{2}$. They found that NPP increased from $12 \%$ to $50 \%$ ( 0.12 to $0.50 \% / y r)$ over virtually all of Canada during the 100 years. Precise numbers could not be extracted from their maps. Because $\mathrm{CO}_{2}$ fertilization was not included, this positive result is likely conservative (Loehle 2018).

Girardin et al. (2011a) combined tree ring records, forest inventory data, fire extent records, and a productivity model to estimate historical patterns of net ecosystem productivity (NEP) over the period 1830-1999 in jack pine forests of the Canadian southern boreal zone just east of the Great Lakes.
They found that over this period, annual fire extent declined, leading to a mean age shift in jack pine from 87 years in the 1920 s to 131 years in 1999. Furthermore, a significant upward trend in NEP was found and attributed to increased precipitation and longer growing seasons during the period 1901-2009. At the same time, because older stands of jack pine are less productive, forest aging after the 1930s reduced carbon assimilation $12 \%$, enough to offset the climate effect (mainly warming) in $75 \%$ of their ensemble of simulations. They noted that forest age structure can complicate interpretations of historical trends.

Notaro et al. (2005) used an Earth-system model to simulate global vegetation during 1900-2000. The model allowed vegetation to respond instantly to climate. The model did not include fire but did include $\mathrm{CO}_{2}$ fertilization. They found a $+2.66 \%$ increase in boreal summer tree cover (not separated by continent). They also found a greening to strong greening (their Fig. 9a) across Canada except for a browning region south and southwest of Hudson Bay. Note that this is roughly coincident with, but a little farther east than other studies showing growth declines cited herein.

The growth models cited here were able to account for stand aging effects, which plot-based studies sometimes fail to do. With this factored in, these studies all mostly found forest growth enhancements over the past 100 years.

\section{Plot-based reconstructions}

Historical reconstructions based on permanent plots and/or tree ring records have the potential to provide reliable data, although ongoing tree mortality should be considered in such studies. Wang et al. (2006) used age-matched tree ring records for white spruce in southwest Manitoba over 19001999 to evaluate growth responses. By using the growth residual after climate factors were modeled, they were able to show that for similar ages, young trees were growing better than old trees at the same ages. They also found that there was a faster recovery from drought in young trees, attributed to effects of $\mathrm{CO}_{2}$ enrichment. The extent of growth enhancements was not quantified.

Hember et al. (2012) studied unmanaged, temperate-maritime forests in southwest British Columbia, accounting for expected stand age-specific growth for stands of multiple ages. They found net stem wood growth to have been increasing at $0.43 \pm 0.12 \% / y r$ over the period $1959-1998$ and that $\mathrm{CO}_{2}$, temperature, and moisture were each partially predictive.

Several studies focused on Alberta and Saskatchewan. Chen and Luo (2015) used 871 permanent plots in Alberta and Saskatchewan to obtain age-adjusted, plot-based, aboveground biomass growth over time for the period 1958-2011. For deciduous, mixed, and early successional conifer types, there was an AGB growth decline of about $-2.4 \% / y r$ and for late-successional conifers of about $-11.1 \% / \mathrm{yr}$ comparing start and end dates. Boisvenue et al. (2016) used both field plots and remote sensing to develop growth estimates for the southern, managed forests of Saskatchewan. Here, we only report the plot-based estimates, which used the age-based Hoerl function growth model. Over the period 1984-2012, they estimated a positive AGB trend of $+1.76 \% / y$ r. Hogg et al. (2017) studied white spruce in Saskatchewan and Alberta in 75 stands. By choosing trees free of competition and convert- 
ing ring measurements to above ground biomass, they largely overcame problems with ring standardization, though they did note that their measures were per tree rather than per unit area. Due to a severe drought over 2001-2002 and poor recovery following the drought, they found a $16 \%$ drop in $\triangle \mathrm{AGB}$ for the 2001-2010 decade compared to the 1991-2000 decade. Some stands did show increased growth. For this decadal-scale comparison, age effects were not a major source of bias.

Searle and Chen (2017a) examined 1797 permanent sample plots across Alberta, Saskatchewan, and Manitoba spanning 1958-2013. Over the period, broadleaf trees and earlysuccessional conifers increased in relative abundance while late-successional conifers decreased. Late-successional conifers were predominantly older (>150 yr) and broadleaf trees and early-successional conifers were mainly younger $(<100 \mathrm{yr})$. They concluded that broadleaf species and earlysuccessional conifers have been favored by rising $\mathrm{CO}_{2}$, and that rising temperatures favored early- vs. late-successional conifers. They did not find moisture to explain compositional changes. The observed increase in relative abundance of younger, faster-growing trees could have increased self-thinning mortality and moisture stress. Luo and Chen (2013) studied a subset of 887 of these same inventory plots for Alberta and Saskatchewan sampled between 1958 and 2007. They found that both self-thinning and warming increased mortality over the period, with moist-site, late successional species, including white spruce, suffering more mortality. Similarly, Jiang et al. (2016) found drought stress in Alberta to have increased during 1985-2010, with white spruce suffering more than aspen.

The final two studies also focused on interior western Canada. Chen et al. (2016) studied plots in interior western Canada with data from 1958-2011. They found a temporal increase in tree growth in young stands at least partially due to rising $\mathrm{CO}_{2}$. Older stands were fairly static in biomass and unresponsive to $\mathrm{CO}_{2}$. A temporal trend of rising mortality was attributed mainly to rising competition (stand dynamics). In interior western Canada during 1958-2009, Zhang et al. (2015) found that competition dominated climate impacts. They used three indices of stand-level competition and consistently found competition to decrease growth and increase mortality. There was no correlation of moisture deficit with mortality when competition was included in the model. There was a small effect of high summer temperature on mortality.

The plot-based studies we could locate were spatially unbalanced, with one in British Columbia, one in Quebec, none in more easterly Canada, and seven in western Canada. The studies available did use extensive networks of inventory plots.

\section{Summary by Region}

\section{Coastal British Columbia}

The western coastal areas have a maritime climate and higher productivity than the interior. While yellow cedar decline has been noted (Buma et al. 2017), most other species seem to be experiencing enhanced growth (Notaro et al. 2005; Del Grosso et al. 2008; Hember et al. 2012, 2017a, 2017b; Wu et al. 2014; Tei et al. 2017). Several studies have documented elevational rises in tree line (Brink 1959; Laroque et al. 2000; Jackson et al. 2016), none of them dramatic.

\section{Interior Western Canada}

Western interior Canada has been well-studied, but contradictions exist. Some studies have reported forest expanding over long periods into grassland or tundra (Szeicz and MacDonald 1995; MacDonald et al. 1998; Masek 2001; Danby and Hik 2007; Conway and Danby 2014; Jackson et al. 2016), but slowly (Caccianiga and Payette 2006). Positive growth trends in the interior west have been reported (Nussbaum 1999; Huang et al. 2004; Notaro et al. 2005; Wang et al. 2006; Del Grosso et al. 2008; Girardin et al. 2011b; Boisvenue et al. 2016; Chen et al. 2016; Tei et al. 2017) with some negative trends (Chen and Luo 2015; Hogg et al. 2017) and mixed results in the interior northwest (Tei et al. 2017). The trend was found by Hember et al. (2017b) to be negative during 1951-2012 but positive during 1961-2012 due to large temporal fluctuations in climate. Notaro et al. (2005) found growth enhancements over the entire West except for a region south and west of Hudson Bay. Girardin et al. (2014) found recent declines south of Hudson's Bay using two methods. Several studies documented or inferred recent increases in mortality (Hogg et al. 2005, 2008; Michaelian et al. 2011; Peng et al. 2011; Luo and Chen 2013; Walker et al. 2015; Jiang et al. 2016; Hember et al. 2017a) mostly in the west-central region, though Thorpe and Daniels (2012), Chen et al. (2016), and Zhang et al. (2015) attributed much of the rising mortality to stand dynamics (self-thinning and aging).

\section{Eastern Canada}

Results for eastern Canada are more consistent than those for interior western Canada. Slow elevational (Payette 2007) and latitudinal (Lavoie and Payette 1994; Lescop-Sinclair and Payette 1995; Caccianiga and Payette 2006; Payette 2007) expansion has been documented. Growth enhancements were found by Gamache and Payette (2004), Notaro et al. (2005), Girardin et al. (2011a, 2012) and Hember et al. (2017b). Local declines were found by Ouimet et al. (2013) for white spruce and by Girardin et al. (2014) for black spruce. Thus, the weight of evidence suggests that widespread growth increases in this region have been reliably detected, with some local declines.

\section{Discussion}

Several aspects of methods and data used in the reviewed studies warrant consideration when interpreting results. As discussed earlier, factors such as changes over time in stand density and age can influence analyses based on tree ring data. Unusual events in a region, such as uncharacteristically high or low severity of natural disturbances, can make extrapolation to wider areas problematic. Finally, in a few studies, causes of growth rate changes could be partitioned to some extent (e.g., Wang et al. 2006; Girardin et al. 2011b for $\mathrm{CO}_{2}$ effects), but in most reviewed papers, the authors could only infer possible causes of trends. Nevertheless, quantifiable growth enhancements, some large, over up to 100-year timeframes, are evident in the eastern half of Canada and western coastal regions. The Canadian western interior has shown slow forest expansion at elevational, latitudinal, and grassland ecotones over long time horizons, but recent (over the last 30 years) trends are ambiguous, with evidence of both increased growth and drought stress. Considerable uncertainty arises from stand dynamics. 
Our study points out the difficulty of quantifying forest growth trends. If a stand is aging and storing less carbon, it is technically growing more slowly over time, but a true sense of growth trends needs to consider stand age. Because stands in Canada are typically initiated by a fire or insect kill event or by harvesting, and are thus roughly even-aged, they can be expected to follow a predictable growth path over time (Fig. 1). This explains the differences between our results and Marchand et al. (2018) and between plot or tree ring data and models.

For determining trends, it is important to keep in mind that climate fluctuates a great deal, especially in interior regions, causing multi-decadal variations in growth (Hogg et al. 2005; Wong and Daniels 2017) with effects also due to pathogens and insects (Morin et al. 1993; Hogg et al. 2005). This can result in a trend that varies from positive to negative depending purely on the period studied (per Hember et al. 2017b). If the most recent period under study is during a drought, a sharp downturn (decline) might be inferred when it is actually unknown if the drought will continue or for how long. Conversely, if earlier sampled periods coincided with drought, an upward growth trend might be inferred.

Canadian forests are subject to large-scale insect outbreaks that can kill large areas of trees. While it has been hypothesized that such attacks could be increasing, a study (Axelson et al. 2015) of western spruce budworm (Choristoneura occidentalis) in central British Columbia over a 435year period did not find a trend. Separating insect and disease histories from other disturbances is outside the scope of our study, but trends are possible and deserve further investigation. An additional consideration is other disturbance regimes such as fire, which are extensive (e.g., White et al. 2017) and may be increasing in size and extent (Hanes et al. 2019). Our concern here has been with growth rates per se, not carbon storage. While fire can reduce forest carbon, its main effect on productivity is to shift the forest toward deciduous or early successional conifer species, which have a higher growth rate. We did not attempt to quantify this effect.

The weight of evidence from reviewed studies indicates that, in many regions, growth relations have been changing over time. An assumption underlying yield tables and site index curves is that short-term weather fluctuations will average out over the life of a forest stand, making growth projections mostly reliable. If conditions change radically over decades, however, such relations could be altered. Hember et al. (2012) found evidence for such site index non-stationarity. Very few studies found temporally stable growth rates in any region of Canada. In areas with rising growth rates, yield tables and site index curves, even from the 1980s, might significantly underestimate growth. Conversely, in areas such as interior western Canada where recent growth reductions may exist due to drought, projections may over-estimate growth. A general ongoing effect is rising $\mathrm{CO}_{2}$ which accelerates early tree growth (Loehle 1995; LaDeau and Clark 2001) thus potentially distorting yield tables and site index curves, favoring some species more than others. Also, as $\mathrm{CO}_{2}$ rises, trees become more fecund at an earlier age (LaDeau and Clark 2001), with implications for seed orchards and recovery after large fires.

\section{Acknowledgments}

Work funded by the National Council for Air and Stream Improvement, Inc. Thanks to K. Vice and T.B. Wigley for helpful suggestions. The authors assert no conflicts of interest.

\section{References}

Addington, R.N. et al. 2018. Principles and practices for the restoration of ponderosa pine and dry mixed-conifer forests of the Colorado Front Range. USDA For. Serv. Gen. Tech. Rpt. RMRSGTR-373.

Alfaro, R.I., J. Berg and J. Axelson. 2014. Periodicity of western spruce budworm in southern British Columbia, Canada. For. Ecol. Manag. 315: 72-79. doi:10.1016/j.foreco.2013.12.026.

Allen, C.D., D.D. Breshears and N.G. McDowell. 2015. On underestimation of global vulnerability to tree mortality and forest die-off from hotter drought in the Anthropocene. Ecosph. 6(8): 129. doi:10.1890/es15-00203.1.

Allen, C.D. et al. 2010. A global overview of drought and heatinduced tree mortality reveals emerging climate change risks for forests. For. Ecol. Manag. 259: 660-684. doi:10.1016/j.foreco. 2009.09.001

Anderegg, W.R.L., A. Flint, C.-Y. Huang, L. Flint, J.A. Berry, F.W. Davis, J.S. Sperry and C.B. Field. 2015. Tree mortality predicted from drought-induced vascular damage. Nat. Geosci. 8(5): 367-371. doi:10.1038/ngeo2400.

Axelson, J.N., D.J. Smith, L.D. Daniels and R.I. Alfaro. 2015. Multicentury reconstruction of western spruce budworm outbreaks in central British Columbia, Canada. For. Ecol. Manag. 335: 235-248. doi:10.1016/j.foreco.2014.10.002.

Baret, M., S. Pepin and D. Pothier. 2018. Hydraulic limitations in dominant trees as a contributing mechanism to the age-related growth decline of boreal forest stands. For. Ecol. Manag. 427: 135142. doi:10.1016/j.foreco.2018.05.043.

Bergeron, Y., M. Flannigan, S. Gauthier, A. Leduc and P. Lefort. 2004. Past, current and future fire frequency in the Canadian boreal forest: Implications for sustainable forest management. Ambio 33(6): 356-360. doi.org/10.1579/0044-7447-33.6.356.

Berner, L.T., P.S.A. Beck, A.G. Bunn, A.H. Lloyd and S.J. Goetz. 2011. High-latitude tree growth and satellite vegetation indices: Correlations and trends in Russia and Canada (1982-2008). J. Geophys. Res. 116(G1): G01015. doi:10.1029/2010jg001475.

Beschta, R.L., L.E. Painter, T. Levi and W.J. Ripple. 2016. Longterm aspen dynamics, trophic cascades, and climate in northern Yellowstone National Park. Can. J. For. Res. 46(4): 548-556. doi:10.1139/cjfr-2015-0301.

Boisvenue, C. and S.W. Running. 2006. Impacts of climate change on natural forest productivity - evidence since the middle of the 20th century. Global Change Biol. 12(5): 862-882. doi.org/10.1111/ j.1365-2486.2006.01134.x.

Boisvenue, C., B.P. Smiley, J.C. White, W.A. Kurz and M.A. Wulder. 2016. Integration of Landsat time series and field plots for forest productivity estimates in decision support models. For. Ecol. Manag. 376: 284-297. doi:10.1016/j.foreco.2016.06.022.

Bond-Lamberty, B., A.V. Rocha, K. Calvin, B. Holmes, C. Wang and M.L. Goulden. 2014. Disturbance legacies and climate jointly drive tree growth and mortality in an intensively studied boreal forest. Glob. Change Biol. 20(1): 216-227. doi:10.1111/gcb.12404.

Bontemps, J.-D., J.-C. Hervé and J.-F. Dhôte. 2009. Long-term changes in forest productivity: A consistent assessment in even-aged stands. For. Sci. 55(6): 549-564. doi:10.1093/forestscience/55.6.549. Bontemps, J.-D., J.-C. Hervé, J.-M. Leban and J.-F. Dhôte. 2011. Nitrogen footprint in a long-term observation of forest growth over the twentieth century. Trees 25(2): 237-251. doi:10.1007/s00468010-0501-2. 
Brink, V.C. 1959. A directional change in the subalpine forestheath ecotone in Garibaldi Park, British Columbia. Ecol. 40(1): 1016. doi:10.2307/1929917.

Brooks, J.R., L.B. Flanagan and J.R. Ehleringer. 1998. Responses of boreal conifers to climate fluctuations: Indications from tree-ring widths and carbon isotope analyses. Can. J. For. Res. 28(4): 524-533. doi:10.1139/x98-018.

Brown, C.D. and M. Vellend. 2014. Non-climatic constraints on upper elevational plant range expansion under climate change. Proc. R. Soc. B 281(1794):20141779. doi:10.1098/rspb.2014.1779.

Buermann, W., P.R. Bikash, M. Jung, D.H. Burn and M. Reichstein. 2013. Earlier springs decrease peak summer productivity in North American boreal forests. Env. Res. Lett. 8(2): 024027. doi:10.1088/1748-9326/8/2/024027.

Buma, B., P.E. Hennon, C.A. Harrington, J.R. Popkin, J. Krapek, M.S. Lamb, L.E. Oakes, S. Saunders and S. Zeglen. 2017. Emerging climate-driven disturbance processes: Widespread mortality associated with snow-to-rain transitions across $10^{\circ}$ of latitude and half the range of a climate-threatened conifer. Global Change Biol. 23(7): 2903-2914. doi:10.1111/gcb.13555.

Caccianiga, M. and S. Payette. 2006. Recent advance of white spruce (Picea glauca) in the coastal tundra of the eastern shore of Hudson Bay (Québec, Canada). J. Biogeogr. 33(12): 2120-2135. doi:10.1111/j.1365-2699.2006.01563.x.

Carrer, M. 2011. Individualistic and time-varying tree-ring growth to climate sensitivity. PLoS ONE 6(7): e22813. doi.org/10.1371/journal.pone.0022813.

Chen, H.Y.H. and Y. Luo. 2015. Net aboveground biomass declines of four major forest types with forest ageing and climate change in western Canada's boreal forests. Glob. Change Biol. 21(10): 36753684. doi:10.1111/gcb.12994.

Chen, H.Y.H., Y. Luo, P.B. Reich, E.B. Searle and S.R. Biswas. 2016. Climate change-associated trends in net biomass change are age dependent in western boreal forests of Canada. Ecol. Lett. 19(9): 1150-1158. doi:10.1111/ele.12653.

Chen, L., J.-G. Huang, S.A. Alam, L. Zhai, A. Dawson, K.J. Stadt and P.G. Comeau. 2017. Drought causes reduced growth of trembling aspen in western Canada. Glob. Change Biol. 23(7): 28872902. doi:10.1111/gcb.13595.

Chen, L., J.-G. Huang, A. Dawson, L. Zhai, K.J. Stadt, P.G. Comeau and C. Whitehouse. 2018. Contributions of insects and droughts to growth decline of trembling aspen mixed boreal forests of western Canada. Glob. Change Biol. 24(2): 655-667. doi:10.1111/gcb.13855.

Cherubini, P., M. Dobbertin and J.L. Innes. 1998. Potential sampling bias in long-term forest growth trends reconstructed from tree rings: A case study from the Italian Alps. For. Ecol. Manag. 109(13): 103-118. doi.org/10.1016/S0378-1127(98)00242-4.

Conway, A.J. and R.K. Danby. 2014. Recent advance of forestgrassland ecotones in southwestern Yukon. Can. J. For. Res. 44(5): 509-520. doi:10.1139/cjfr-2013-0429.

Danby, R.K. and D.S. Hik. 2007. Variability, contingency and rapid change in recent subarctic alpine tree-line dynamics. J. Ecol. 95(2): 352-363. doi:10.1111/j.1365-2745.2006.01200.x.

De Kauwe, M.G., T.F. Keenan, B.E. Medlyn, I.C. Prentice and C. Terrer. 2016. Satellite based estimates underestimate the effect of $\mathrm{CO}_{2}$ fertilization on net primary productivity. Nat. Clim. Change 6(10): 892-893. doi.org/10.1038/nclimate3105.

Del Grosso, S., W. Parton, T. Stohlgren, D. Zheng, D. Bachelet, S. Prince, K. Hibbard and R. Olson. 2008. Global potential net primary production predicted from vegetation class, precipitation, and temperature. Ecol. 89(8): 2117-2126. doi.org/10.1890/07-0850.1.

Dietrich, R., F.W. Bell, L.C.R. Silva, A. Cecile, W.R. Horwath and M. Anand. 2016. Climatic sensitivity, water-use efficiency, and growth decline in boreal jack pine (Pinus banksiana) forests in northern Ontario. J. Geophys. Res.: Biogeosci. 121(10): 2761-2774. doi:10.1002/2016jg003443.
Dunn, A.L., C.C. Barford, S.C. Wofsy, M.L. Goulden and B.C. Daube. 2007. A long-term record of carbon exchange in a boreal black spruce forest: means, responses to interannual variability, and decadal trends. Global Change Biol. 13(3): 577-590. doi:10.1111/ j.1365-2486.2006.01221.x.

Esper, J., D.C. Frank and R.J.S. Wilson. 2004. Climate reconstructions-low frequency ambition and high frequency ratification. EOS Trans. Am. Geophy. Union 85(12): 113-120. doi:10.1029/ 2004EO120002.

Esper, J., D.C. Frank, R.J.S. Wilson and K.R. Briffa. 2005a. Effect of scaling and regression on reconstructed temperature amplitude for the past millennium. Geophys. Res. Lett. 32(7): L07711. doi:10.1029/2004GL021236.

Esper, J., R.J.S. Wilson, D.C. Frank, A. Moberg, H. Wanner and J. Luterbacher. 2005b. Climate: Past ranges and future changes. Quat. Sci. Rev. 24(20-21): 2164-2166. doi:10.1016/j.quascirev.2005.07.001. Esper, J., D.C. Frank and J. Luterbacher. 2007. On selected issues and challenges in dendroclimatology. In: F. Kienast, O. Wildi, and S. Ghosh (eds.). A changing world: challenges for landscape research. pp. 113-132. Netherlands, Springer.

Forrester, D.I. 2019. Linking forest growth with stand structure: Tree size inequality, tree growth or resource partitioning and the asymmetry of competition. For Ecol. Manag. 447: 139-157. doi:10.1016/j.foreco.2019.05.053.

Foster, J.R., A.O. Finley, A.W. D'Amato, J.B. Bradford and S. Banerjee. 2016. Predicting tree biomass growth in the temperateboreal ecotone: Is tree size, age, competition, or climate response most important? Global Change Biol. 22(6): 2138-2151. doi:10.1111/gcb.13208.

Franke, J., D. Frank, C.C. Raible, J. Esper and S. Brönnimann. 2013. Spectral biases in tree-ring climate proxies. Nat. Clim. Change 3(4): 360-364. doi:10.1038/nclimate1816.

Frey, B.R., V.J. Lieffers, E.H. Hogg and S.M. Landhäusser. 2004. Predicting landscape patterns of aspen dieback: Mechanisms and knowledge gaps. Can. J. For. Res. 34(7): 1379-1390. doi:10.1139/ x04-062.

Gamache, I. and S. Payette. 2004. Height growth response of treeline black spruce to recent climate warming across the forest-tundra of eastern Canada. J. Ecol. 92(5): 835-845. doi:10.1111/j.00220477.2004.00913.x

Gillett, N.P., A.J. Weaver, F.W. Zwiers and M.D. Flannigan. 2004. Detecting the effect of climate change on Canadian forest fires. Geophys. Res. Lttr. 31(18): L18211. doi:10.1029/2004gl020876.

Girardin, M.P., P.Y. Bernier and S. Gauthier. 2011a. Increasing potential NEP of eastern boreal North American forests constrained by decreasing wildfire activity. Ecosphere 2(3): 1-23. doi.org/ 10.1890/ES10-00159.1.

Girardin, M.P., P.Y. Bernier, F. Raulier, J.C. Tardif, F. Conciatori and X.J. Guo. 2011b. Testing for a $\mathrm{CO}_{2}$ fertilization effect on growth of Canadian boreal forests. J. Geophys. Res. 116(G1): G01012. doi:10.1029/2010jg001287.

Girardin, M.P., X.J. Guo, P.Y. Bernier, F. Raulier and S. Gauthier. 2012. Changes in growth of pristine boreal Northern American forests from 1950 to 2005 driven by landscape demographics and species traits. Biogeosci. 9(7): 2523-2536. doi:10.5194/bg-9-2523-2012. Girardin, M.P., X.J. Guo, R. de Jong, C. Kinnard, P. Bernier and F. Raulier. 2014. Unusual forest growth decline in boreal North America covaries with the retreat of Arctic sea ice. Global Change Biol. 20(3): 851-866. doi:10.1111/gcb.12400.

Girardin, M.P. et al. 2016a. No growth stimulation of Canada's boreal forest under half-century of combined warming and $\mathrm{CO}_{2}$ fertilization. Proc. Natl. Acad. Sci. 113(52): E8406-E8414. doi:10.1073/ pnas. 1610156113

Girardin, M.P., E.H. Hogg, P.Y. Bernier, W.A. Kurz, X.J. Guo and G. Cyr. 2016b. Negative impacts of high temperatures on growth of black spruce forests intensify with the anticipated climate warming. Global Change Biol. 22(2): 627-643. doi:10.1111/gcb.13072. 
Goulden, M.L., A.M.S. McMillan, G.C. Winston, A.V. Rocha, K.L. Manies, J.W. Harden and B.P. Bond-Lamberty. 2011. Patterns of NPP, GPP, respiration, and NEP during boreal forest succession. Global Change Biol. 17(2): 855-871. doi:10.1111/j.13652486.2010.02274.x.

Guay, K.C., P.S.A. Beck, L.T. Berner, S.J. Goetz, A. Baccini and W. Buermann. 2014. Vegetation productivity patterns at high northern latitudes: A multi-sensor satellite data assessment. Global Change Biol. 20(10): 3147-3158. doi:10.1111/gcb.12647.

Hanes, C.C., X. Wang, P. Jain, M.-A. Parisien, J.M. Little and M.D. Flannigan. 2019. Fire-regime changes in Canada over the last half century. Can. J. For. Res. 49(3): 256-269. doi:10.1139/cjfr-20180293.

Harsch, M.A., P.E. Hulme, M.S. McGlone and R.P. Duncan. 2009. Are tree-lines advancing? A global meta-analysis of tree-line response to climate warming. Ecol. Lett. 12(10): 1040-1049. doi:10.1111/j.1461-0248.2009.01355.x.

Hember, R.A., W.A. Kurz, J.M. Metsaranta, T.A. Black, R.D. Guy and N.C. Coops. 2012. Accelerating regrowth of temperate-maritime forests due to environmental change. Glob. Change Biol. 18(6): 2026-2040. doi:10.1111/j.1365-2486.2012.02669.x.

Hember, R.A., W.A. Kurz and N.C. Coops. 2017a. Relationships between individual-tree mortality and water-balance variables indicate positive trends in water stress-induced tree mortality across North America. Global Change Biol. 23(4): 1691-1710. doi:10.1111/ gcb.13428.

Hember, R.A., W.A. Kurz and N.C. Coops. 2017b. Increasing net ecosystem biomass production of Canada's boreal and temperate forests despite decline in dry climates. Glob. Biogeochem. Cycles 31(1): 134-158. doi:10.1002/2016gb005459.

Higginbotham, K.O., J.M. Mayo, S. L'Hirondelle and D.K. Krystofiak. 1985. Physiological ecology of lodgepole pine (Pinus contorta) in an enriched $\mathrm{CO}_{2}$ environment. Can. J. For. Res. 15(2): 417-421. doi:10.1139/x85-067.

Hogg, E.H., J.P. Brandt and B. Kochtubajda. 2005. Factors affecting interannual variation in growth of western Canadian aspen forests during 1951-2000. Can. J. For. Res. 35(3): 610-622. doi:10.1139/x04-211.

Hogg, E.H., J.P. Brandt and M. Michaelian. 2008. Impacts of a regional drought on the productivity, dieback, and biomass of western Canadian aspen forests. Can. J. For. Res. 38(6): 1373-1384. doi:10.1139/X08-001.

Hogg, E.H., M. Michaelian, T.I. Hook and M.E. Undershultz. 2017. Recent climatic drying leads to age-independent growth reductions of white spruce stands in western Canada. Global Change Biol. 23(12): 5297-5308. doi:10.1111/gcb.13795.

Huang, S., R.A. Monserud, T. Braun, H. Lougheed and $O$. Bakowsky. 2004. Comparing site productivity of mature fire-origin and post-harvest juvenile lodgepole pine stands in Alberta. Can. J. For. Res. 34(6): 1181-1191. doi:10.1139/x04-009.

Jackson, M.M., E. Topp, S.E. Gergel, K. Martin, F. Pirotti and T. Sitzia. 2016. Expansion of subalpine woody vegetation over 40 years on Vancouver Island, British Columbia, Canada. Can. J. For. Res. 46(3): 437-443. doi:10.1139/cjfr-2015-0186.

Jiang, X., J.-G. Huang, K.J. Stadt, P.G. Comeau and H.Y.H. Chen. 2016. Spatial climate-dependent growth response of boreal mixedwood forest in western Canada. Global Planet. Change 139: 141150. doi:10.1016/j.gloplacha.2016.02.002.

Johnstone, J.F. and F.S. Chapin. 2003. Non-equilibrium succession dynamics indicate continued northern migration of lodgepole pine. Glob. Change Biol. 9(10): 1401-1409. doi:10.1046/j.13652486.2003.00661.x.

Kashian, D.M., W.H. Romme, D.B. Tinker, M.G. Turner and M.G. Ryan. 2013. Postfire changes in forest carbon storage over a 300-year chronosequence of Pinus contorta-dominated forests. Ecol. Monogr. 83(1): 49-66. doi:10.1890/11-1454.1.
Kearney, M.S. 1982. Recent seedling establishment at timberline in Jasper National Park, Alta. Can. J. Bot. 60: 2283-2287. doi:10.1139/b82-279. doi:10.1139/b82-279.

Kohyama, T.S., T.I. Kohyama and D. Sheil. 2019. Estimating net biomass production and loss from repeated measurements of trees in forests and woodlands: Formulae, biases and recommendations. For. Ecol. Manag. 433: 729-740. doi:10.1016/j.foreco.2018.11.010.

Kurz, W. and M.J. Apps. 1999. A 70-year retrospective analysis of carbon fluxes in the Canadian forest sector. Ecol. Appl. 9(2): 526547. doi:10.1890/1051-0761(1999)009[0526:ayraoc]2.0.co;2.

LaDeau, S.L. and J.S. Clark. 2001. Rising $\mathrm{CO}_{2}$ levels and the fecundity of forest trees. Science 292(5514): 95-98. doi.org/10.1126/science.1057547.

Laroque, C.P., D.H. Lewis and D.J. Smith. 2000. Tree-line dynamics on southern Vancouver Island, British Columbia. West. Geogr. 10/11: 43-63.

Lavoie, C. and S. Payette. 1994. Recent fluctuations of the lichenspruce forest limit in subarctic Québec. J. Ecol. 82(4): 725-734. doi:10.2307/2261438.

Lenoir, J., J.C. Gégout, P.A. Marquet, P. de Ruffray and H. Brisse. 2008. A significant upward shift in plant species optimum elevation during the $20^{\text {th }}$ century. Science 320(5884): 1768-1771. doi:10.1126/ science. 1156831.

Lescop-Sinclair, K. and S. Payette. 1995. Recent advance of the arctic tree-line along the eastern coast of Hudson Bay. J. Ecol. 83(6): 929-936. doi:10.2307/2261175.

Lieffers, V.J., D. Sidders, T. Keddy, K.A. Solarik and P. Blenis. 2018. A partial canopy of aspen, coupled with site preparation produces excellent growth of planted spruce. Can. J. For. Res. doi:10.1139/cjfr-2018-0310.

Loehle, C. 1988. Tree life history strategies: The role of defenses. Can. J. For. Res. 18(2): 209-222. doi:10.1139/x88-032.

Loehle, C. 1995. Anomalous responses of plants to $\mathrm{CO}_{2}$ enrichment. OIKOS 73(2): 181-187. doi:10.2307/3545906.

Loehle, C. 1996. Optimal defensive investments in plants. Oikos 75(2): 299-302. doi:10.2307/3546253.

Loehle, C. 2018. Disequilibrium and relaxation times for species responses to climate change. Ecol. Model. 384: 23-29. doi:10.1016/j.ecolmodel.2018.06.004.

Loehle, C., C. Idso and T.B. Wigley. 2016. Physiological and ecological factors influencing recent trends in United States forest health responses to climate change. For. Ecol. Manag. 363: 179-189. doi.org/10.1016/j.foreco.2015.12.042.

Luo, Y. and H.Y.H. Chen. 2013. Observations from old forests underestimate climate change effects on tree mortality. Nat. Commun. 4: 1655. doi:10.1038/ncomms2681.

Ma, Z., C. Peng, Q. Zhu, H. Chen, G. Yu, W. Li, X. Zhou, W. Wang and W. Zhang. 2012. Regional drought-induced reduction in the biomass carbon sink of Canada's boreal forests. Proc. Natl. Acad. Sci. 109(7): 2423-2427. doi:10.1073/pnas.1111576109.

MacDonald, G.M., J.M. Szeicz, J. Claricoates and K.A. Dale. 1998. Response of the central Canadian tree-line to recent climatic changes. Ann. Assoc. Am. Geogr. 88(2): 183-208. doi:10.1111/14678306.00090 .

Marchand, W., M.P. Girardin, S. Gauthier, H. Hartmann, O. Bouriaud, F. Babst and Y. Bergeron. 2018. Untangling methodological and scale considerations in growth and productivity trend estimates of Canada's forests. Environ. Res. Lett. 13(9): 093001. doi:10.1088/1748-9326/aad82a.

Martínez-VilaltaM, J. and F. Loret. 2016. Drought-induced vegetation shifts in terrestrial ecosystems: The key role of regeneration dynamics. Glob. Planet. Change 144: 94-108. doi:10.1016/j.gloplacha.2016.07.009.

Masek, J.G. 2001. Stability of boreal forest stands during recent climate change: Evidence from Landsat satellite imagery. J. Biogeogr. 28(8): 967-976. doi:10.1046/j.1365-2699.2001.00612.x. 
McDowell, N.G. and C.D. Allen. 2015. Darcy's law predicts widespread forest mortality under climate warming. Nat. Clim. Change 5(7): 669-672. doi.org/10.1038/nclimate2641.

McDowell, N.G. et al. 2016. Multi-scale predictions of massive conifer mortality due to chronic temperature rise. Nat. Clim. Change 6(3): 295-300. doi.org/10.1038/nclimate2873.

Metsaranta, J.M., J.A. Trofymow, T.A. Black and R.S. Jassal. 2018. Long-term time series of annual ecosystem production (19852010) derived from tree rings in Douglas-fir stands on Vancouver Island, Canada using a hybrid biometric-modelling approach. For. Ecol. Manag. 429: 57-68. doi:10.1016/j.foreco.2018.06.040.

Michaelian, M., E.H. Hogg, R.J. Hall and E. Arsenault. 2011. Massive mortality of aspen following severe drought along the southern edge of the Canadian boreal forest. Global Change Biol. 17(6): 20842094. doi:10.1111/j.1365-2486.2010.02357.x.

Morin, H., D. Laprise and Y. Bergeron. 1993. Chronology of spruce budworm outbreaks near Lake Duparquet, Abitibi region, Quebec. Can. J. For. Res. 23(8): 1497-1506. doi:10.1139/x93-189.

Nehrbass-Ahles, C., F. Babst, S. Klesse, M. Nötzli, O. Bouridaud, R. Neukom, M. Dobbertin and D. Frank. 2014. The influence of sampling design on tree-ring-based quantification of forest growth. Global Change Biol. 20(9): 2867-2885. doi.org/10.1111/gcb.12599.

Nelson, M.D. and G.A. Reams. 2017. Is the area of US forests increasing or decreasing? For. Source 22: 16-17, 21. www.nxtbook. com/nxtbooks/saf/forestrysource_201705/index.php\#/1.

Notaro, M., Z. Liu, R. Gallimore, S.J. Vavrus, J.E. Kutzbach, I.C. Prentice and R.L. Jacob. 2005. Simulated and observed preindustrial to modern vegetation and climate changes. J. Clim. 18(17): 3650-3671. doi:10.1175/JCLI3501.1.

Nussbaum, A.F. 1998. Site index adjustments for old-growth stands based on paired plots. B.C. Min. For. Res. Prog. Work. Pap. 37.

Ouimet, R., J.-D. Moore, L. Duchesne and C. Camiré. 2013. Etiology of a recent white spruce decline: Role of potassium deficiency, past disturbances, and climate change. Can. J. For. Res. 43(1): 66-77. doi:10.1139/cjfr-2012-0344.

Painter, L.E., R.L. Beschta, E.J. Larsen and W.J. Ripple. 2014. After long-term decline, are aspen recovering in northern Yellowstone? For. Ecol. Manag. 329: 108-117. doi:10.1016/j.foreco. 2014.05.055.

Payette, S. 2007. Contrasted dynamics of northern Labrador treelines caused by climate change and migrational lag. Ecology 88(3): 770-780. doi:10.1890/06-0265.

Payette, S., L. Filion, A. Delwaide and C. Bégin. 1989. Reconstruction of tree-line vegetation response to long-term climate change. Nature 341(6241): 429-432. doi:10.1038/341429a0.

Pederson, N. et al. 2015. Climate remains an important driver of post-European vegetation change in the eastern United States. Global Change Biol. 21(6): 2105-2110. https://doi.org/10.1111/ gcb.12779.

Peng, C. et al. 2011. A drought-induced pervasive increase in tree mortality across Canada's boreal forests. Nat. Clim. Change 1(9): 467-471. doi:10.1038/nclimate1293.

Pregitzer, K.S. and E.S. Euskirchen. 2004. Carbon cycling and storage in world forests: Biome patterns related to forest age. Global Change Biol. 10: 2052-2077. doi:10.1111/j.1365-2486.2004.00866.x. Rooney, T.P. 2001. Deer impacts on forest ecosystems: A North American perspective. Forestry 74(3): 201-208. doi:10.1093/ forestry/74.3.201.

Rundel, P.W., I.A. Dickie and D.M. Richardson. 2014. Tree invasions into treeless areas: Mechanisms and ecosystem processes. Biol. Invasions 16(3): 663-675. doi:10.1007/s10530-013-0614-9.

Schulte-Uebbing, L. and W. de Vries. 2018. Global-scale impacts of nitrogen deposition on tree carbon sequestration in tropical, temperate, and boreal forests: A meta-analysis. Global Change Biol. 24(2): e416-e431. doi:10.1111/gcb.13862.
Searle, E.B. and H.Y.H. Chen. 2017a. Persistent and pervasive compositional shifts of western boreal forest plots in Canada. Global Change Biol. 23(2): 857-866. doi:10.1111/gcb.13420.

Searle, E.B. and H.Y.H. Chen. 2017b. Tree size thresholds produced biased estimates of forest biomass dynamics. For. Ecol. Manag. 400: 468-474. doi:10.1016/j.foreco.2017.06.042.

Serreze, M.C. et al. 2000. Observational evidence of recent change in the northern high-latitude environment. Climatic Change 46(12): 159-207. doi:10.1023/A:1005504031923.

Smith, W.K., S.C. Reed, C.C. Cleveland, A.P. Ballantyne, W.R.L. Anderegg, W.R. Wieder, Y.Y. Liu and S.W. Running. 2016. Large divergence of satellite and Earth system model estimates of global terrestrial $\mathrm{CO}_{2}$ fertilization. Nat. Clim. Change 6(3): 306-310. doi:10.1038/nclimate2879.

Solarik, K.A., C. Messier, R. Ouimet, Y. Bergeron and D. Gravel. 2018. Local adaptation of trees at the range margins impacts range shifts in the face of climate change. Global Ecol. Biogeogr. 27(12): 1507-1519. doi:10.1111/geb.12829.

Stephenson, N.L., P.J. van Mantgem, A.G. Bunn, H. Bruner, M.E. Harmon, K.B. O'Connell, D.L. Urban and J.F. Franklin. 2011. Causes and implications of the correlation between forest productivity and tree mortality rates. Ecol. Monog. 81(4): 527-555. doi.org/10.1890/10-1077.1.

Stevens, N., C.E.R. Lehmann, B.P. Murphy and G. Durigan. 2017. Savanna woody encroachment is widespread across three continents. Global Change Biol. 23(1): 235-244. doi:10.1111/gcb.13409.

Szeicz, J.M. and G.M. MacDonald. 1995. Recent white spruce dynamics at the subarctic alpine tree-line of north-western Canada. J. Ecol. 83(5): 873-885. www.jstor.org/stable/2261424.

Talbot, J. et al. 2014. Methods to estimate aboveground wood productivity from long-term forest inventory plots. For. Ecol. Manag. 320: 30-38. doi:10.1016/j.foreco.2014.02.021.

Taylor, A.H., V. Trouet, C.N. Skinner and S. Stephens. 2016. Socioecological transitions trigger fire regime shifts and modulate fire-climate interactions in the Sierra Nevada, USA, 1600-2015 CE. Proc. Natl. Acad. Sci. 113(48): 13684-13689. https://doi.org/ 10.1073/pnas.1609775113.

Tei, S., A. Sugimoto, H. Yonenobu, Y. Matsuura, A. Osawa, H. Sato, J. Fujinuma and T. Maximov. 2017. Tree-ring analysis and modeling approaches yield contrary response of circumboreal forest productivity to climate change. Glob. Change Biol. 23(12): 51795188. doi:10.1111/gcb.13780.

Ter-Mikaelian, M.T., S.J. Colombo, D. Lovekin, J. McKechnie, R. Reynolds, B. Titus, E. Laurin, A.-M. Chapman, J. Chen and H.L. Maclean. 2015. Carbon debt repayment or carbon sequestration parity: Lessons from a forest bioenergy case study in Ontario, Canada. Global Change Biol. Bioenerg. 7: 704-716. doi:10.1111/ gcbb. 12198 .

Thorpe, H.C. and L.D. Daniels. 2012. Long-term trends in tree mortality rates in the Alberta foothills are driven by stand development. Can. J. For. Res. 42(9): 1687-1696. doi:10.1139/x2012-104.

von Storch, H., E. Zorita, J.M. Jones, Y. Dimitriev, F. GonzálezRouco and S.F.B. Tett. 2004. Reconstructing past climate from noisy data. Sci. 306(5696): 679-682. doi:10.1126/science.1096109.

Walker, X.J., M.C. Mack and J.F. Johnstone. 2015. Stable carbon isotope analysis reveals widespread drought stress in boreal black spruce forests. Global Change Biol. 21(8): 3102-3113. doi:10.1111/ gcb.12893.

Wang, G.G., S. Chhin and W.L. Bauerle. 2006. Effect of natural atmospheric $\mathrm{CO}_{2}$ fertilization suggested by open-grown white spruce in a dry environment. Global Change Biol. 12(3): 601-610. doi:10.1111/j.1365-2486.2006.01098.x.

Wang, R. et al. 2017. Global forest carbon uptake due to nitrogen and phosphorus deposition from 1850 to 2100. Global Change Biol. 23(11): 4854-4872. doi:10.1111/gcb.13766. 
Watson, E. and B.H. Luckman. 2002. The dendroclimatic signal in Douglas-fir and ponderosa pine tree-ring chronologies from the southern Canadian Cordillera. Can. J. For. Res. 32(10): 1858-1874. doi:10.1139/x02-096.

White, J.C., M.A. Wulder, T. Hermosilla, N.C. Coops and G.W. Hobart. 2017. A nationwide annual characterization of 25 years of forest disturbance and recovery for Canada using Landsat time series. Remote Sens. Environ. 194: 303-321. doi:10.1016/j.rse.2017. 03.035 .

Wong, C.M. and L.D. Daniels. 2017. Novel forest decline triggered by multiple interactions among climate, an introduced pathogen and bark beetles. Glob. Change Biol. 23(5): 1926-1941. doi:10.1111/gcb.13554.

Worrall, J.J., G.E. Rehfeldt, A. Hamann, E.H. Hogg, S.B. Marchetti, M. Michaelian and L.K. Gray. 2013. Recent declines of Populus tremuloides in North America linked to climate. For. Ecol. Manag. 299: 35-51. doi.org/10.1016/j.foreco.2012.12.033.
Wu, C., R.A. Hember, J.M. Chen, W.A. Kurz, D.T. Price, C. Boisvenue, A. Gonsamo and W. Ju. 2014. Accelerating forest growth enhancement due to climate and atmospheric changes in British Columbia, Canada over 1956-2001. Sci. Rep. 4: 4461. doi:10.1038/srep04461.

Yang, R.C. 2006. Foliage and stand growth responses of semimature lodgepole pine to thinning and fertilization. Can. J. For. Res. 28(12): 1794-1804. doi.org/10.1139/x98-148.

Zhang, J., S. Huang and F. He. 2015. Half-century evidence from western Canada shows forest dynamics are primarily driven by competition followed by climate. Proc. Natl. Acad. Sci. 112(13): 4009-4014. doi:10.1073/pnas.1420844112. 